\title{
PINHEIROS: AS RESILIÊNCIAS DE UM SÍTIO URBANO
}

PINHEIROS: RESILIENCES OF AN URBAN NEIGHBORHOOD

\section{NoEmi Yolan NAgy Fritsch}

Professora das disciplinas de Paisagismo na Faculdade de Arquitetura e Urbanismo CEUNSP e MAX PLANCK; Especialista em Plantas Ornamentais e Paisagismo pela UFLA.

E-mail: noemi.projetos@gmail.com

\section{RESUMO}

O presente artigo tem como objetivo verificar se a área envoltória do que conhecemos hoje como Largo da Batata, no bairro de Pinheiros, é um ponto de resiliência social e urbana dentro da cidade de São Paulo. As análises das diversas ocupações do sítio urbano de Pinheiros, tradicional bairro paulistano, desde a sua ocupação oficial, em 1560, pelos padres jesuítas, pertencentes à Companhia de Jesus, até as ocupações informais de coletivos urbanos que dela se apropriaram a partir de 2014, são imprescindíveis para tal propósito. Através deles, traçam-se paralelos entre as políticas públicas e conectividades urbanas e movimentos sociais delas decorrentes. Da mesma forma, a abordagem de conceitos como topofilia, locus e genius loci são essenciais para a compreensão dos fenômenos de resiliência, apontados no decorrer desta explanação, ocasionados pelas diversas formas de apropriação deste sítio, considerado um dos mais antigos da cidade de São Paulo.

Palavras-chave: Bairro de Pinheiros; Largo da Batata; Resiliência Social; Resiliência Urbana; Topofilia.

\begin{abstract}
The present article aims to verify if the surrounding area of what we know today as Largo da Batata, in the neighborhood of Pinheiros, is a point of social and urban resilience in São Paulo city. The analyzes of the several occupations of the urban site of Pinheiros, a traditional district of this city, since its official occupation in 1560 by the Jesuit priests, belonging to the Society of Jesus, until the informal occupations of ur-
\end{abstract}


ban collectives that appropriated it since 2014, are essential for this purpose. Through them a parallel may be drawn between public policies and urban connectivities and social movements resulting from them. Likewise, the approach of concepts such as topophilia, locus and genius loci are essential for the comprehension of the resilience phenomena pointed out in the course of this explanation, caused by the various forms of appropriation of this site, considered one of the oldest in the city of São Paulo.

Keywords: Neighborhood of Pinheiros; Largo da Batata; Social Resilience; Urban Resilience; Topophilia.

\section{INTRODUÇÃO}

\section{A FORMA URBANA PRIMITIVA: EM BUSCA DO LOCUS}

A ocupação do território brasileiro é marcada pela irregularidade seja ela geográfica, espacial ou formal. As primeiras cidades fundadas apropriam-se da costa atlântica, acompanhando o extenso litoral e demarcando a posse portuguesa da terra de norte a sul, conveniente para o tráfico. A divisão do território em Capitanias Hereditárias pela Coroa Portuguesa em 1534 é uma breve tentativa de organizar esta ocupação, semelhante ao que havia sido feito em outras colônias portuguesas na llha da Madeira, Açores e Cabo Verde, com dimensões territoriais infinitamente menores do que a brasileira. As distâncias entre os núcleos urbanos eram demasiadamente grandes, dificultando as comunicações e acessos e rareando à medida que se afastam do litoral para o interior, conforme relata MARX (1980, cap. 02).

De um modo geral, as cidades brasileiras foram construídas historicamente, sem projeto, apenas adaptando-se aos relevos e acidentes geográficos dos sítios urbanos e arredores. Seu traçado inicial e elementos espaciais sofreram constantes modificações, conforme seu núcleo inicial se expandia através de um parcelamento de solo peculiar.

A contribuição indígena para a fixação dos primeiros assentamentos portugueses foi de extrema importância. Em 1532, quando Martim Afonso de Souza, primeiro donatário da capitania de São Vicente, desembarca no litoral, já encontra no local um povoado habitado por europeus e indígenas. Pouco há para se fazer, além de apoiar as lideranças locais tratando-as com deferência para, desta forma, conseguir realizar sua 
missão de fundação de vilas (KATINSKY, 1976 pág.158). Com a cooperação dos nativos sobe para o planalto em trilhas indígenas e descobre sítios propícios para seus propósitos (Fig. 01).

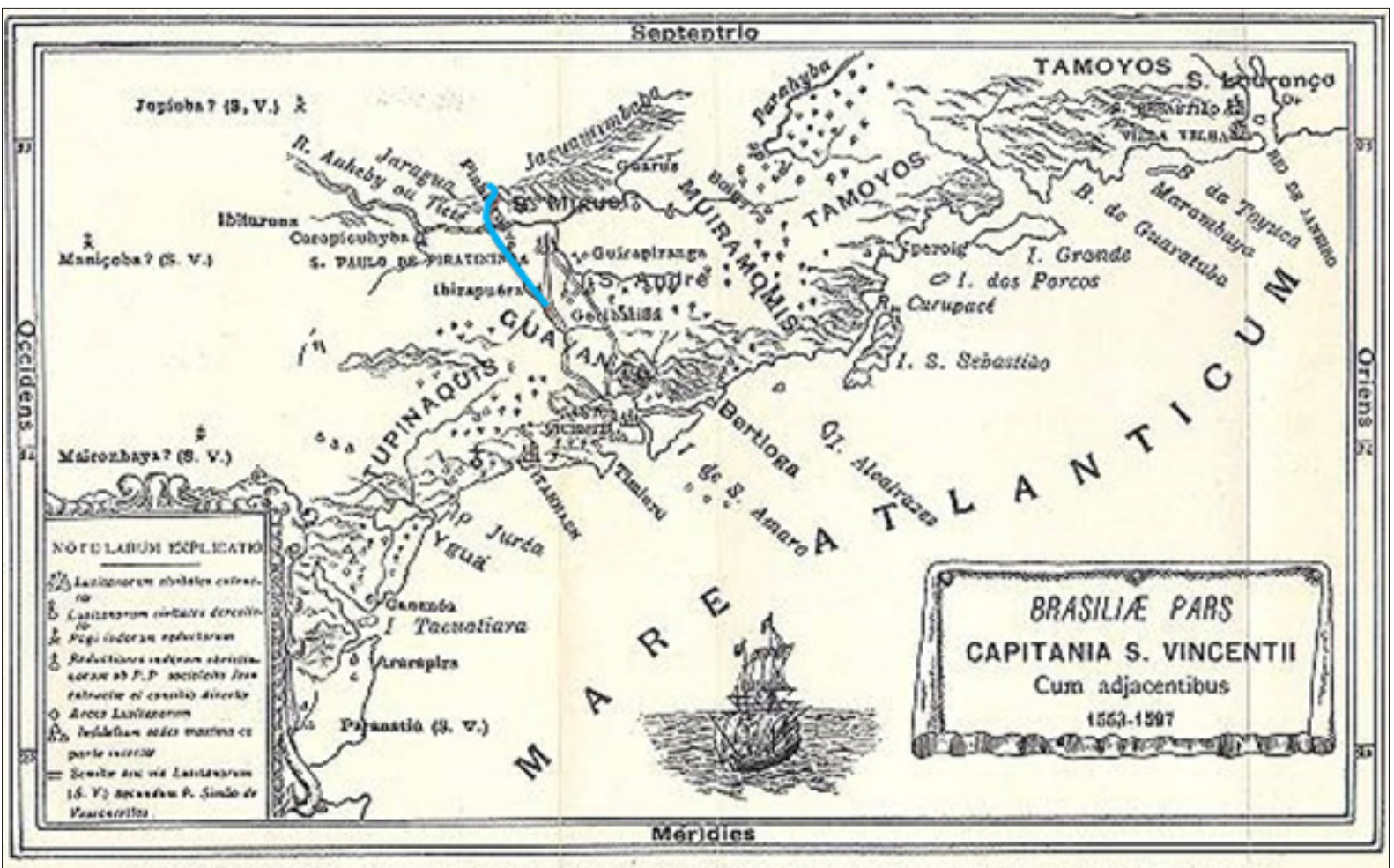

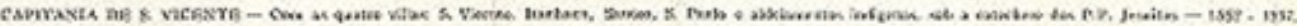

Figura 01. Mapa da Capitania de São Vicente - com as quatro vilas S. Vicente, Itanhaém, Santos, S. Paulo e aldeamentos indígenas, sob a catequese dos padres jesuítas 1532-1597. No destaque em azul, o Rio Pinheiros. Organizado pela autora. Fonte: <http://www.novomilenio.inf.br/santos/mapa17.htm\#1927/> Acesso em 03/06/2018.

A chegada da Companhia de Jesus no Brasil marca o início de um período no qual as redes eclesiásticas precedem a rede civil na constituição dos núcleos populacionais, sendo responsáveis pela oficialização de ermidas de povoados dispersos, elevandoas ao estatuto de capela e garantindo a presença eventual de um pároco para assistência religiosa (BUENO, 2009). A posterior elevação da capela para a categoria de freguesia permite aos moradores terem acesso aos sacramentos do batismo e casamento e respectivos registros de nascimento e matrimônio amparados juridicamente. A capela inicial torna-se uma matriz, permitindo-lhe a construção de uma sacristia. Tanto a solicitação do pedido de elevação ao estatuto de capela como a de freguesia deveria ser solicitada junto ao bispado, que deliberava a favor ou contra os pedidos, movido por interesses próprios ou políticos. 
O processo de escolha de um local para erguer a capela, sua construção e posterior consagração em nome de um santo padroeiro lembra os primitivos rituais de fundação das cidades romanas de inauguratio, limitatio e consacratio. Durante o ritual Inauguratio, o sacerdote consultava a vontade dos deuses para saber se poderia erigir a cidade naquele local, naquele locus.

Segundo Rossi (2001, pág.147), cada sítio é governado por uma divindade única, pertencente ao local, o genius loci. Esta divindade determina as características e essências do local e as construções que ali se encontram e possibilita que formas antigas permaneçam e resistam às transformações, tornando-se uma herança histórico-urbana. " $A$ forma urbana, como produto humano e coletivo, deve ser entendida não somente como uma projeção das forças políticas, econômicas e sociais, que são determinantes, mas também como o resultado da permanência das formas preexistentes" (ZANETTI, 1988 pág. 16).

Considerando que muitas aldeias, inclusive a de Pinheiros, foram assentadas em áreas anteriormente pertencentes aos indígenas, há um choque não apenas de culturas, mas de religiosidades também, uma vez que para os índios tupis-guaranis a migração é de caráter religioso em busca da "terra sem males". Um locus ideal onde se localizam todos os desejos e que se tornam muitas vezes mais relevantes que outros aspectos de suas vidas sociais (FIGUEIREDO, 2012 pág. 47).

A procura por elos afetivos que estabeleçam conexões entre as pessoas e o locus, ambiente físico e princípios da Topofilia (TUAN, 1980) é o ponto de partida para uma nova proposta de leitura sobre as ocupações urbanas na busca de respostas para os fenômenos de resiliência social e urbana. Afinal nullus locus sine Genio. (CARDINALE, 2016 pág. 19).

\section{OS PRIMÓRDIOS: A ALDEIA DE PINHEIROS}

A origem da fundação do sítio urbano de Pinheiros é controversa e depende do ponto de vista de quem a está contando: o nativo (selvagem) ou o visitante (intruso). Para TUAN (1980, cap. 06), esses pontos de vista são essenciais para entendermos as posturas adotadas por cada um deles no momento em que se confrontam pela primeira vez, pois ambos sentem-se ameaçados. Este fato é importante, pois traz consigo diferentes perspectivas, reflexo de culturas, experiências e atitudes ambientais diferentes, não só sobre o território, mas sobre o rio também. 
Temos inicialmente o olhar dos índios tupis, adaptados a um modo de vida nômade, mudando constantemente de lugar - locus, que escolhem os locais temporários de morada baseados na sua experiência de sobrevivência. Nesse caso, mostram-se essenciais a existência de bosques de araucárias que proporcionam frutos alimentícios e constituem-se numa barreira física de defesa do aldeamento; a proximidade de antigas trilhas tupis que lhes permite o deslocamento para o interior, de onde em Araritaguaba (Porto Feliz) conseguem acessar o rio e navegá-lo até o Paraguai; a fundamental presença do rio Jerubatuba, com abundância de peixes encalhados em suas várzeas nas épocas de cheia, que ao morrer e secar ao sol transformam-se em alimento também. O rio para eles não é barreira, suas cheias são sempre benvindas e as várzeas e terraços sempre prontos para o plantio. A presença dos jesuítas não é apreciada, pois são considerados intrusos que lhes tomam a terra, impõe tarefas e tiram-Ihes a autonomia.

Os jesuítas, quando chegam sentem-se ameaçados também. Reivindicam o papel de civilizados que trazem as boas novas da catequese e alcunham os índios de selvagens. Esta atitude defensiva é compreensiva, pois Ihes permite observar os nativos à distância enquanto se apropriam espacialmente do local construindo um núcleo urbano, mesmo que este se restrinja a uma praça, uma capela e parcos casarios. Esta apropriação física é importante, pois muito mais do que marcar a conquista do território, demonstra a superioridade de quem está então no comando. A aldeia é "fruto da adaptação à terra" (LIMA, 2006, pág. 50). A catequese é usada como doutrina para subjugar os índios, tratados como pagãos.

Conforme relatam ZANETTI (1988), AMARAL (1985) e REALE (1982), o núcleo oficial fundado aproveitou-se de uma organização territorial indígena preexistente estabelecendo-se nas proximidades do rio Jerubatuba, na continuidade de uma aldeia indígena em uma plataforma elevada sobre a várzea inundável, onde a travessia do rio era facilitada devido ao estreitamento de suas margens, tornando-se um trecho obrigatório de diversos caminhos que cruzavam a região, sejam de indígenas ou posteriormente de bandeirantes (Fig. 02). 


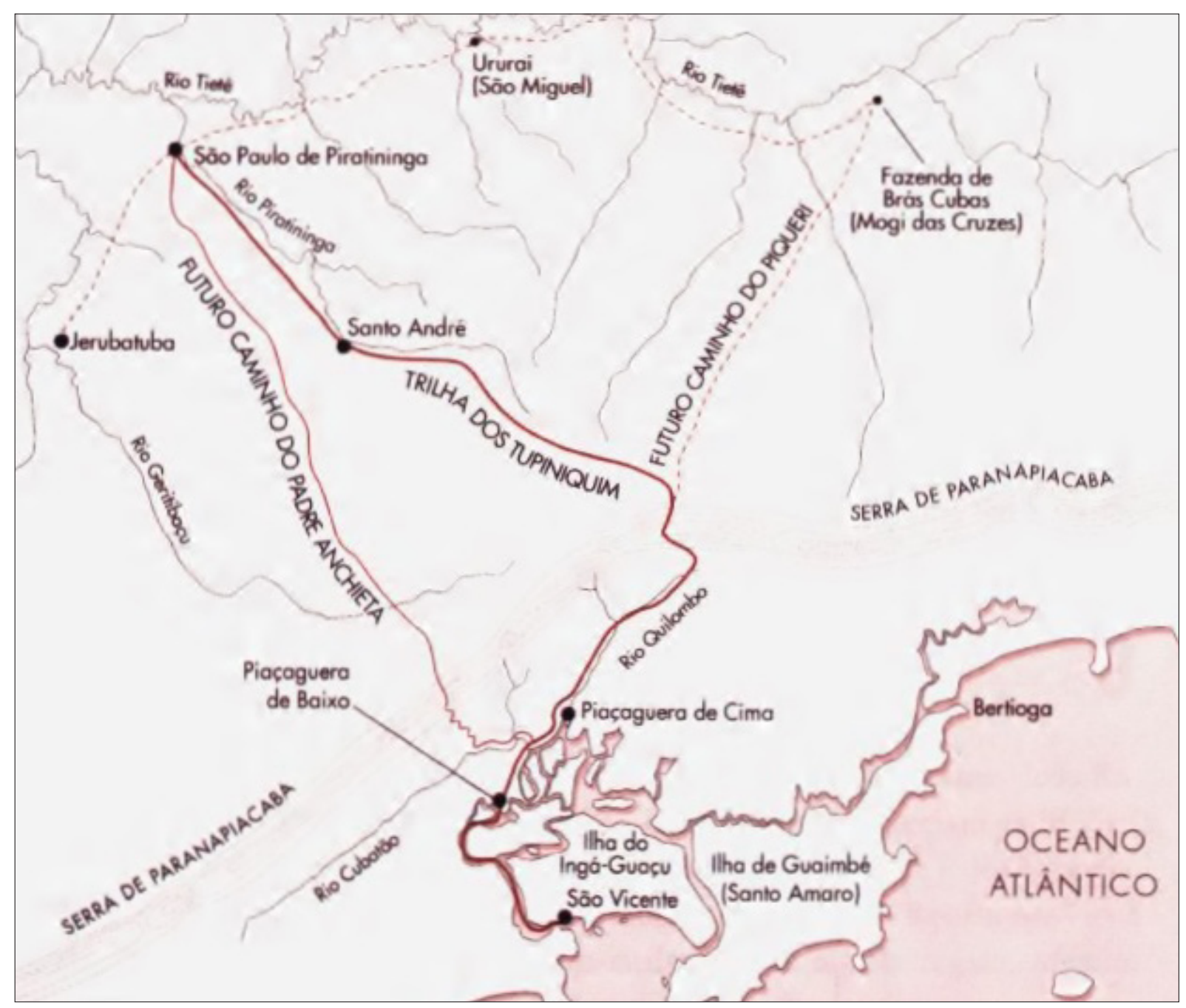

Figuras 02. A Trilha dos Tupiniquins e o Caminho do Padre Anchieta.

Fonte:<http://migre.me/8f3YK/>. Acesso em 03/06/2018.

Do ponto de vista oficial, o ano de 1560 marca a fundação da aldeia indígena de Conceição de Nossa Senhora dos Pinheiros com a edificação de uma capela-residência pelos missionários jesuítas da providência do padre José de Anchieta, no intuito de reunir neste local os habitantes das imediações evitando a sua dispersão e ensinando-Ihes a catequese (KIMURA, 1975 pág. 03). O local escolhido, um terraço fluvial na altitude de 731 metros, localizado à margem direita do rio Jerubatuba, hoje Pinheiros, dista uma légua e meia a sudoeste da vila de São Paulo do Piratininga (Fig. 04). A data de fundação coincide com a extinção da vila de Santo André e transferência de seus moradores para a recém-criada vila de São Paulo de Piratininga, movimento que ocasiona um deslocamento dos indígenas para as terras ditas "desamparadas" nas localidades de Pinheiros e São Miguel (SILVA, 1984, p. 28), 
construindo ali então suas aldeias e evitando a concorrência dos portugueses. Nos relatos de AMARAL (1985 pág. 12), sabe-se que em 1562 o padre Manuel da Nóbrega solicitou ao capitão Pedro Colaço uma légua de terra pertencente à aldeia denominada de Pinheiros, para a edificação de um colégio para a Companhia de Jesus. A intitulação do nome Pinheiros, às vezes atribuída ao bosque de araucárias existente no local, não é confirmada, apesar de vários moradores terem se referido à existência de árvores de espinhos (DICK, 1997, pág.121).

Os primeiros anos de convivência entre os índios e jesuítas na Aldeia de Pinheiros, são marcados um discreto desenvolvimento urbano, contando a vila com 600 pessoas em 1589 (USP, 1963, pág. 91). A catequese e as atividades litúrgicas, administração dos sacramentos e celebração das festas santas é parte do cotidiano desenvolvido na aldeia. Os índios aldeados, "amigos e vizinhos" (LIMA, 2006, pág. 51) embora não sendo escravos, recebem castigos corporais por parte dos jesuítas, por serem considerados pagãos.

Em contrapartida, documentos oficiais atestam que a ocupação das terras para as atividades agrícolas era intensa. Em 13 de outubro de 1582 Jerônimo Leitão, capitão da capitania de São Vicente concede seis léguas de terra aos índios da aldeia de Pinheiros "(...) que até então lavravam na terra dos padres, terras que iam se acabando, necessitando eles de outras, para se poderem sustentar" (AMARAL, 1985, pág. 12), justificando serem índios cristãos. Sabe-se que no ano seguinte os oficiais da câmara da Vila de São Paulo, no dia $1^{\circ}$ de junho, proíbem o acesso e construção de casas nos arredores e nas aldeias de Pinheiros e Ururaí (São Miguel Paulista), com penas variando de multa a seis meses de prisão, devido a condutas inapropriadas para com os nativos. Os aldeamentos impedem aos colonos o acesso direto à mão-de-obra indígena, intermediada pelos jesuítas e a cessão de terras para os nativos cria uma tensão crescente entre eles. Em 1590, a aldeia de Pinheiros é atacada por índios tupiniquins que incendeiam a capela e queimam a imagem de Nossa Senhora do Rosário dos Pinheiros (REALE, 1982, pág. 64), fato que demonstra a insatisfação de outros moradores da região frente aos jesuítas. A capela é reconstruída, mas os anos seguintes acabam sendo marcados pela decadência do aldeamento, causados principalmente pelos movimentos bandeiristas que se iniciam no final do século XVI e causam mudanças administrativas nas vilas coloniais. Em setembro de 1611, promulga-se uma lei que permite a escravização de índios pagãos e a administração dos aldeamentos por colonos, delegando aos padres jesuítas papel secundário. Muitas das missões são atacadas e os índios aprisionados 
e escravizados servindo de mão-de-obra para agricultura e mineração. É a primeira de uma série de intervenções que provocam o esvaziamento das aldeias e culminam na expulsão dos padres jesuítas da vila de São Paulo em 1640.

A capela da aldeia de Pinheiros passa para a ordem dos beneditinos e devoção de Nossa Senhora de Monte Serrat. Mesmo com o esvaziamento da aldeia, que não permite a elevação da capela à categoria de freguesia e o aumento dos poderes administrativos e religiosos (KIMURA, 1975, pág. 04), mantém-se o núcleo do povoamento original, o locus urbis (ROSSI, 2001), no local da edificação da primeira igreja, arquitetura que simboliza a vitória cristã sobre os nativos pagãos e "elemento de atração dos povoadores, inclusive europeus" ( USP, 1963, pág. 94). A oscilação populacional da aldeia, que marca os século XVII e grande parte do século XVIII não prejudica as romarias frequentes da população paulistana ao local da capela. Em 1765 , um recenseamento na aldeia constata apenas 45 habitantes no local, o que preocupa o recém-nomeado governador da capitania de São Paulo, Luiz Antônio de Souza Botelho e Mourão, o Morgado de Matheus, que encontra na capitania muitas aldeias, inclusive a de Pinheiros, em situação de abandono, restando apenas o nome de onde estiveram (REALE, 1982, pág. 65). Em carta datada de dezembro de 1766, ele estabelece medidas para reverter essa situação, estando entre elas a elevação de vários aldeamentos, inclusive o de Pinheiros, à categoria de vila, que implicaria em uma autonomia política e administrativa do povoado. Tal intento acaba não acontecendo, sendo a aldeia de Pinheiros elevada apenas à categoria de freguesia, em 1799, fato que não ocasiona melhoras significativas para seus habitantes.

O fenômeno de resiliência social através da sobrevivência do núcleo original de ocupação da aldeia é incontestável, mas não pode ser desvinculada da questão geográfica de sua localização estratégica sob um terraço fluvial à margem direita do rio Pinheiros, num local de estreitamento de suas margens que facilita a travessia e torna-se passagem obrigatória das trilhas e caminhos indígenas que se dirigem ao sul conectando-se aos territórios do Paraguai, Bolívia e Argentina e para o oeste (Fig. 03). Esse conjunto de caminhos, conhecidos como Peaberu, que em guarani significa "terra sem males", o locus ideal onde se realizam todos os desejos, é uma estrada primitiva que percorre aproximadamente três mil quilômetros desde a Vila de São Vicente às margens do Oceano Atlântico até alcançar o Oceano Pacífico no Peru. No território brasileiro, correspondem às antigas trilhas tupiniquins (Fig. 04). 


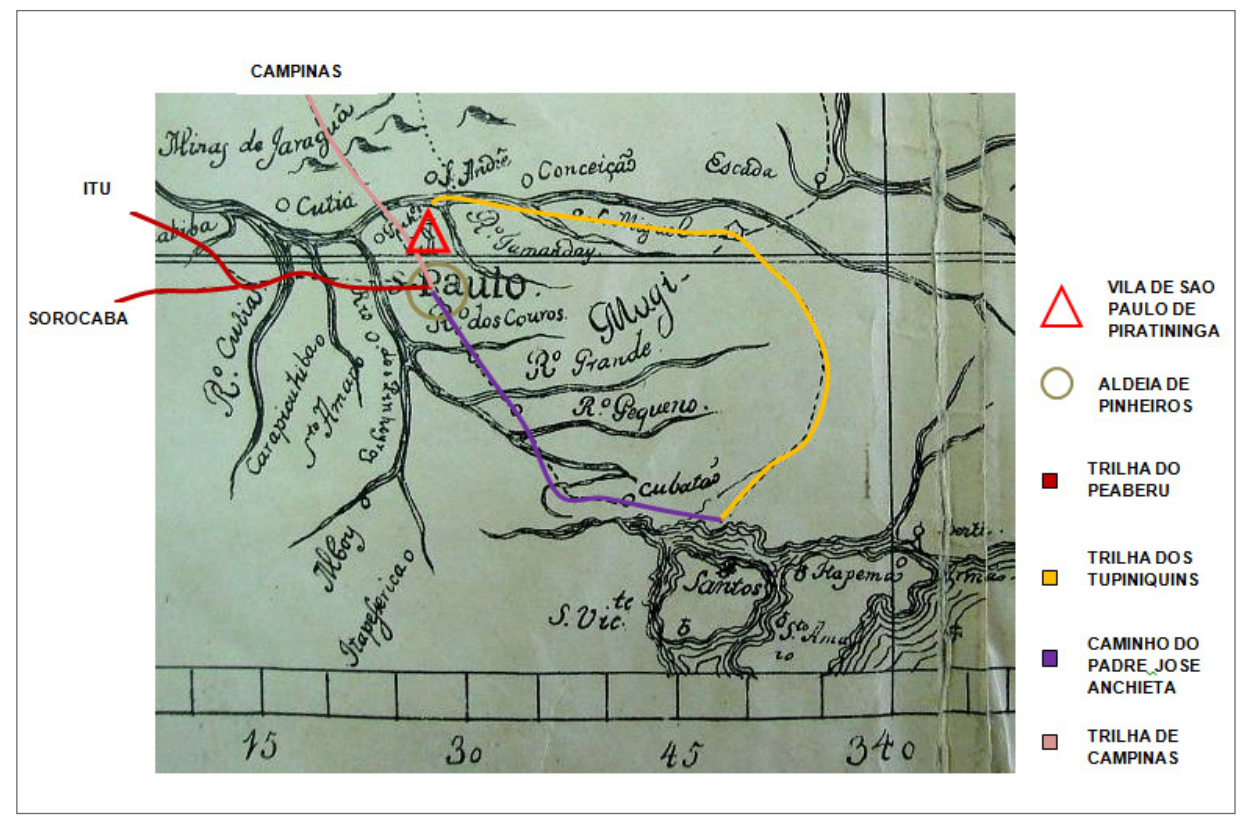

Figura 03. Trilhas indígenas nos arredores da Vila de São Paulo e aldeia de Pinheiros. Adaptado do original Mapa de Santos. Carta corográfica - Capitania. de S. Paulo, 1766 (Da Fazenda de Brás Cubas em Mogi das Cruzes, do Caminho do Padre José de Anchieta, ao Alto da Serra, Núcleo Embrião de Piquete). Organizado pela autora. Fonte:< https:// Ih3.googleusercontent.com/proxy/5gY8OySQnN9Q8bIRpdIOoX2EYvW4XTyMWViID7F MTuKa_Z_jWVLiOMelHUoMUVzHh_FQG0h9onkFd3GKtItni4e706YhL9uBKwKT=s0-d/> Acesso em 10/06/2018.

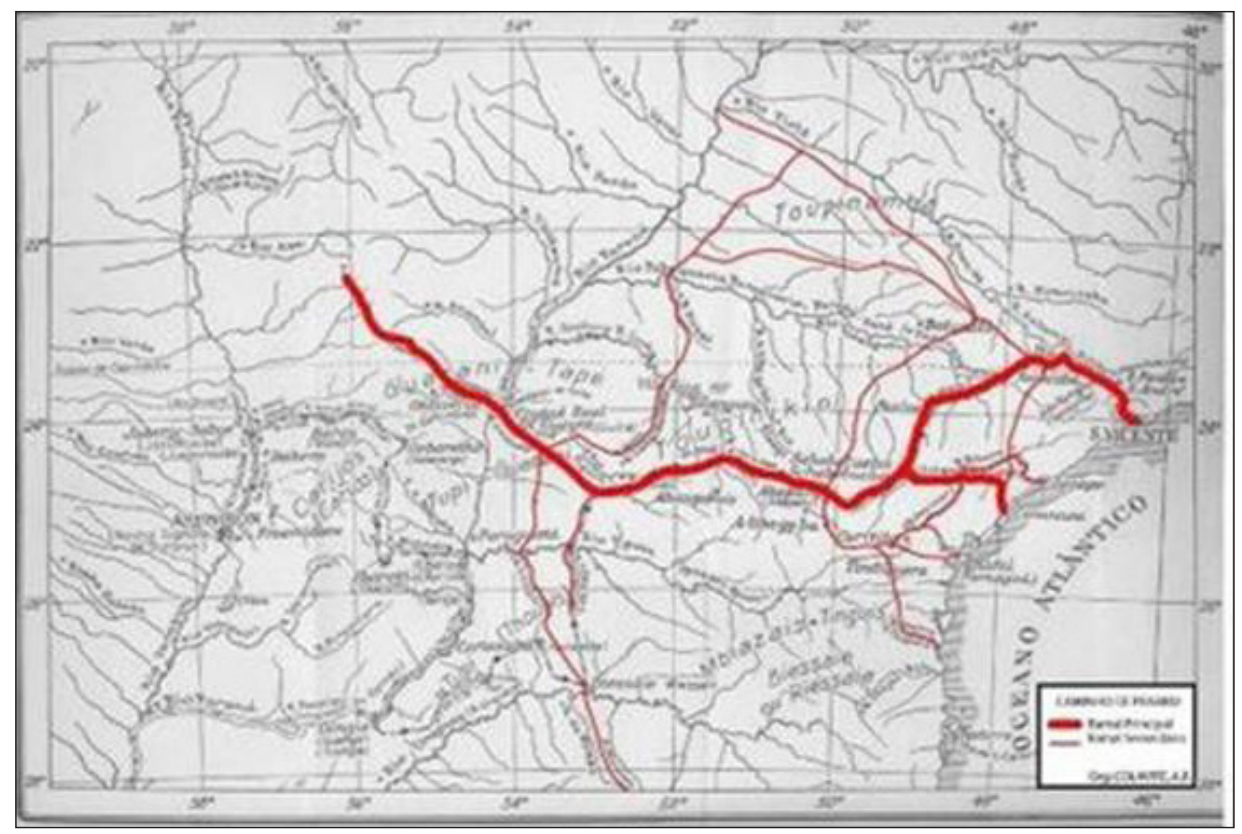

Figura 04. O Caminho de Peaberu - antiga trilha dos Tupiniquins. Itinerário de Ulrich Schmidel com o Caminho de Peabiru em destaque. Adaptado de Maack (2002). Organizado por Ana Paula Colavite. Fonte: < http://www.geografia.seed.pr.gov.br/arquivos/ Image/mapa_pr_caminho_peabiru_2.jpg/> Acesso em 10/06/2018. 
A aldeia de Pinheiros, desde cedo, assume a função de "porta de entrada ou saída da vila" (USP, 1963, pág. 101) e a travessia do rio Pinheiros, apesar de não ser muito fundo, dificulta as comunicações com as vilas de Parnaíba, Cotia, Itu e Sorocaba. A falta de uma passagem sobre o rio é motivo de preocupação das autoridades locais e, desde 1632, há registros de pedidos na câmara para a construção de uma ponte sobre o rio (AMARAL, 1985, pág. 31), construída apenas no início do século XVIII. As expensas com as obras deveriam ser repartidas entre os moradores das localidades beneficiadas pela sua travessia. A ponte foi reconstruída inúmeras vezes devido às enchentes do rio Pinheiros e em 1764 foi proibida "a passagem de tropas de cavalos, mulas e boiadas" (REALE, 1982, pág.65), que causavam prejuízos nas estruturas, penalizando-se os infratores com multas e prisão, além do reparo dos danos. A privilegiada localização da aldeia, em termos de conectividades urbanas de caminhos e passagens entre os rios Pinheiros, Tietê e Tamanduateí, é fundamental para o entendimento da resiliência urbana da região nos tempos atuais.

\section{O LARGO DE PINHEIROS: OS CAIPIRAS E AS BATATAS}

A freguesia de Pinheiros, que no ano de 1765 chega a contar com apenas 45 habitantes, começa a ser repovoada gradativamente durante o século XIX, sendo ocupada por um novo segmento populacional composto de mestiços de brancos, negros e mulatos, muitos destes vivendo em comunidades quilombolas espalhadas pelas matas da região. As antigas propriedades jesuíticas confiscadas pela coroa portuguesa e posteriormente doadas a particulares são convertidas em chácaras e sítios onde permanece como atividade principal a agricultura, além do surgimento de olarias, devido à abundância de argila na região. $\mathrm{O}$ núcleo original da aldeia permanece ao redor da pequena capela, na confluência das ruas São João (atual Paes Leme) e a estrada para Sorocaba (atual Rua Butantã) (Fig. 05). 


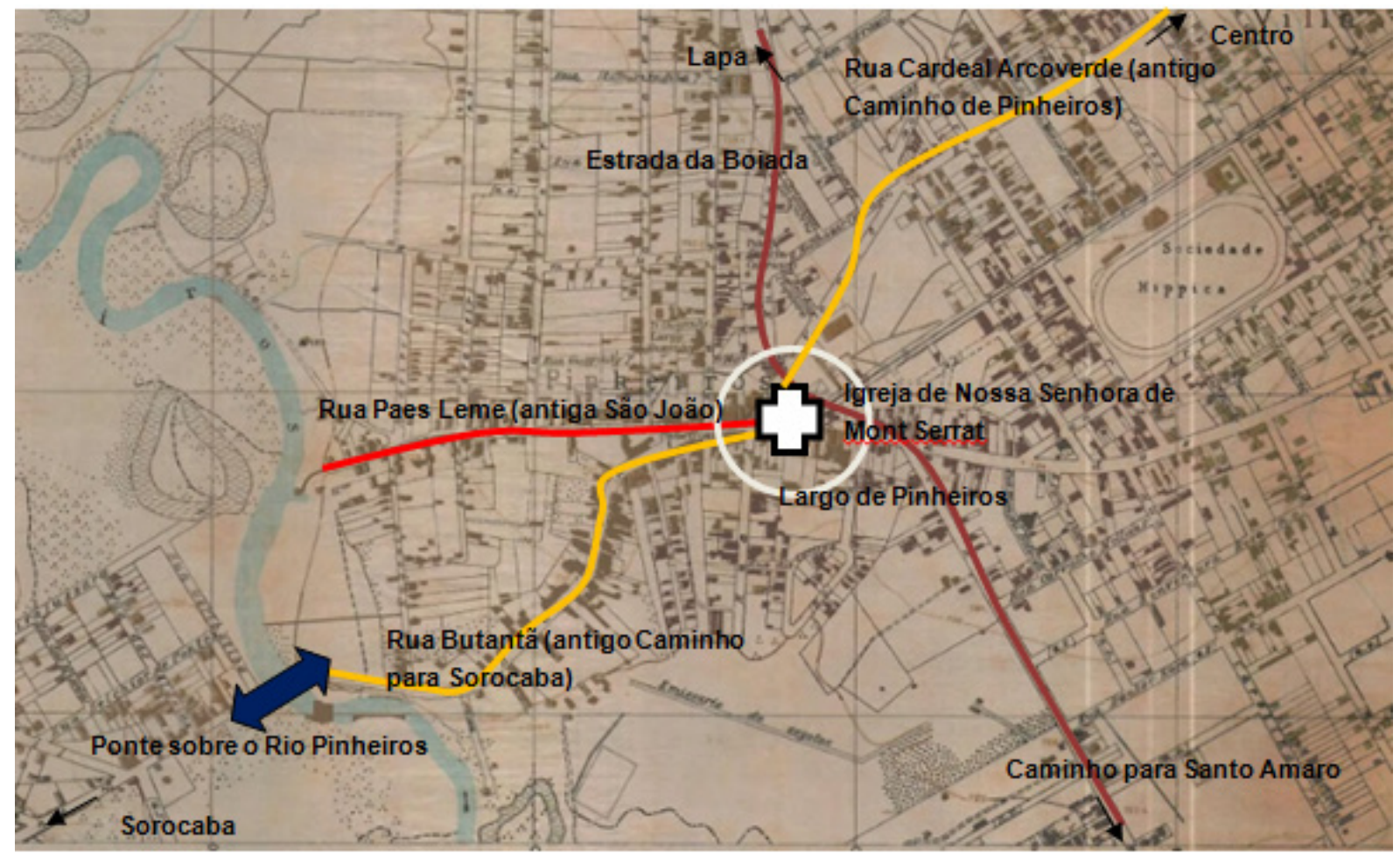

Figura 05. Mapa do núcleo urbano de Pinheiros com os principais caminhos de passagem. Adaptado do mapa Topographico do Município de São Paulo. Sara Brasil, 1930, folha 35. Organizado pela autora. Fonte: <http://geosampa.prefeitura.sp.gov.br/PaginasPublicas/_SBC.aspx /> Acesso em 18/05/2018.

Em 1870, a pedido dos moradores, a antiga capela é demolida e em área próxima constrói-se uma igreja maior, com alicerce em pedra e paredes de tijolos para poder comportar o grande número de fiéis, devotos de Nossa Senhora do Monte Serrat que para lá se dirigem oriundos de toda a cidade de São Paulo, por ocasião das festas e romarias.

O início do ciclo cafeeiro em 1850, no interior paulista, repercute na cidade de São Paulo, que até então não se destaca como potência econômica no país, com uma configuração espacial mais clara com a separação de bairros por atividades e grupos sociais (ROLNIK, 2003, pág. 18). O capital gerado pelo café, a criação de uma elite burguesa, a implantação de ferrovias ligando as zonas produtoras ao porto de Santos e a chegada de centenas de imigrantes europeus para trabalhar nas fazendas, transformam a cidade. A chegada de imigrantes alemães e italianos ao bairro movimenta o comércio local, com a instalação de novos comércios como padarias, além de um pouso de tropeiros, olarias e carvoarias. 
Novos bairros residenciais vão sendo criados para atender esta elite e uma rede de infraestruturas urbanas começa a ser implementada: pavimentação de ruas, implantação do serviço de transporte urbano por bondes, movidos primeiro a tração animal (1872), posteriormente substituído pelos elétricos (1900), além do fornecimento de energia elétrica para as residências e indústrias e telefonia.

A repercussão desse desenvolvimento urbano em Pinheiros acontece de modo mais lento, integrando aos poucos o restante do município aos habitantes e grandes áreas vazias do bairro. A construção da ponte metálica sobre o rio Pinheiros em 1865, montada por João Reinfranck é um dos primeiros reflexos deste desenvolvimento (Fig. 06), permitindo um acesso mais seguro e contínuo para os bairros e interior.

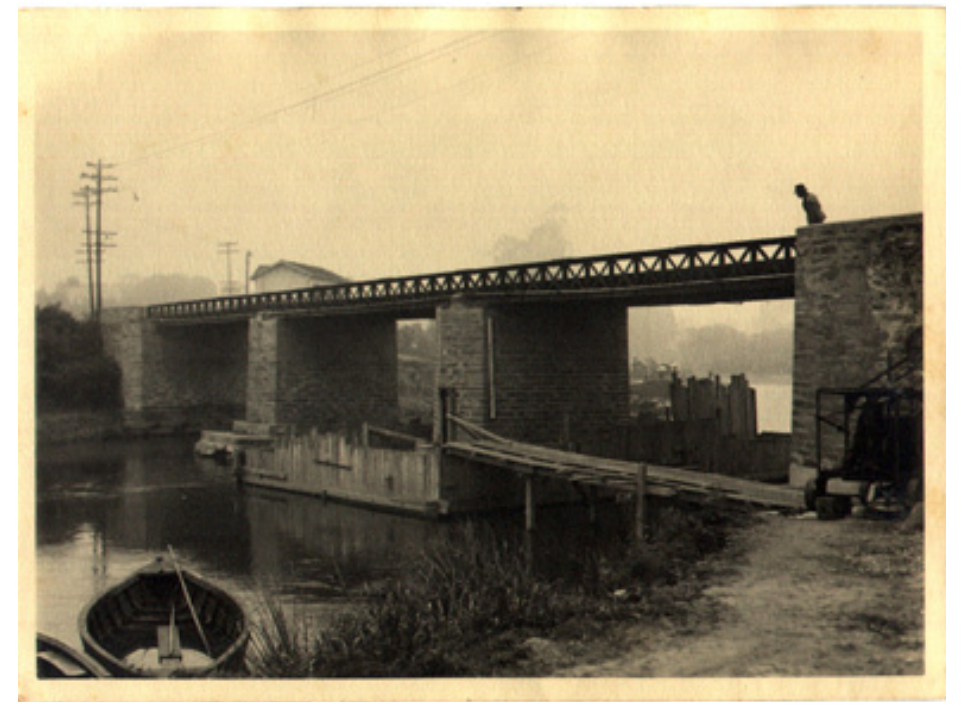

Figura 06. Antiga ponte sobre o Rio Pinheiros. Fonte:< http://www.arquiamigos.org.br/foto/images/1/0169.jpg/> Acesso em 18/05/2018.

A facilidade de acesso a outras vilas e bairros a partir da ponte e a posterior construção de uma estrada de ligação entre o Caminho de Pinheiros e os campos de Santo Amaro, através de decreto da câmara em 1786, prolongado depois até a Lapa, em trecho denominado Estrada da Boiada, possibilita o desenvolvimento de um entreposto agrícola na região do largo de Pinheiros, em 1907, para a comercialização dos produtos dos sítios localizados no entorno, abrangendo os municípios de Cotia e Itaquaquecetuba, denominados como cinturão caipira. Em 1910 inaugura-se o mercado rural de Pinheiros, em chácara doada por antigo morador, localizada em frente à Igreja Matriz, apelidado de Mercado dos Caipiras (Fig. 07). A posterior inauguração da Cooperativa Agrícola de Cotia (CAC) em 1928 em terreno próximo ao mercado, por imigrantes japoneses que se estabelecem no bairro e cidades do cinturão verde, reforça o caráter 
comercial e atacadista de Pinheiros. O nome Largo da Batata é oriundo desta época, devido à comercialização de batatas pela cooperativa (Fig. 08).
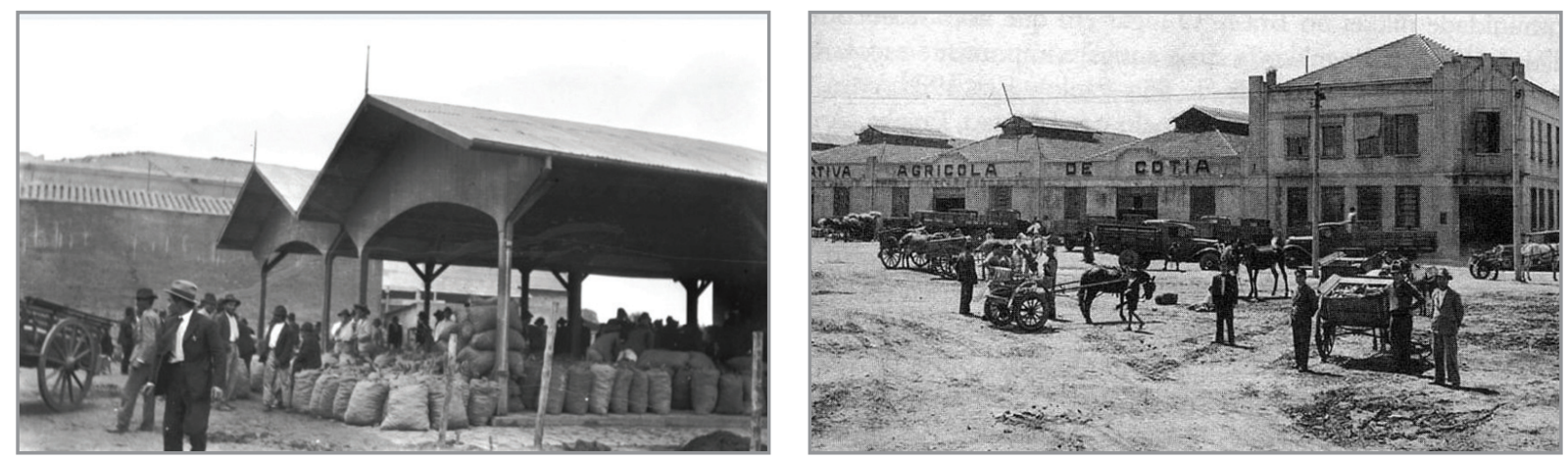

Figuras 07 e 08. Antigo mercado dos Caipiras e Cooperativa Agrícola de Cotia. Fonte:< https://www. researchgate.net/publication/314293058/figure/fig2/AS:469767887822849@1489012800817/Figura2-Antigo-Mercado-dos-Caipiras-anos-1910-/> e < http://www.imigracaojaponesa.com.br/wp-content/ uploads/2012/06/cooperativa-sede-pinheiros2.jpg/> respectivamente. Acesso em 18/05/2018.

Paralelamente ao cotidiano dos caipiras pobres de Pinheiros e da comunidade nipônica, por influência dos loteamentos da Companhia City que começam a ocupar áreas próximas ao bairro, estabelecem-se nas margens do Rio Pinheiros clubes burgueses como o Germânia, fundado por alemães em 1899, para práticas esportivas, posteriormente renomeado como Clube Pinheiros e, em 1953, o Clube Hebraica, criado para ser um ponto de encontro para descendentes da comunidade hebraica. Na Rua Teodoro Sampaio, funda-se em 1911 a Sociedade Hípica Paulista, ponto de encontro da elite paulistana da época. Aos poucos, inicia-se a ocupação das áreas próximas da Rua Iguatemi, continuidade da Estrada da Boiada na direção de Santo Amaro.

Paradoxalmente a este crescimento e prestígio, o bairro de Pinheiros mantem-se isolado do centro da cidade de São Paulo, tanto pela distância quanto pela dificuldade de acesso devido ao relevo íngreme que separa as duas localidades. Existe apenas um caminho de ligação entre eles, acompanhando "o traçado da atual Cardeal Arcoverde, daí seguindo pelas Estradas do Araçá e de Pinheiros, atual Rua da Consolação" (REALE, 1982, pág. 66), citada por historiadores como trecho das antigas Trilhas dos Tupiniquins, e da trilha do Peaberu.

Mapas da época que retratam a cidade de São Paulo confirmam essa desconexão do centro com as áreas periféricas da cidade, inclusive o bairro de Pinheiros. A primeira vez que o bairro aparece em uma planta da cidade de São Paulo data de 1897 (Fig. 09). 


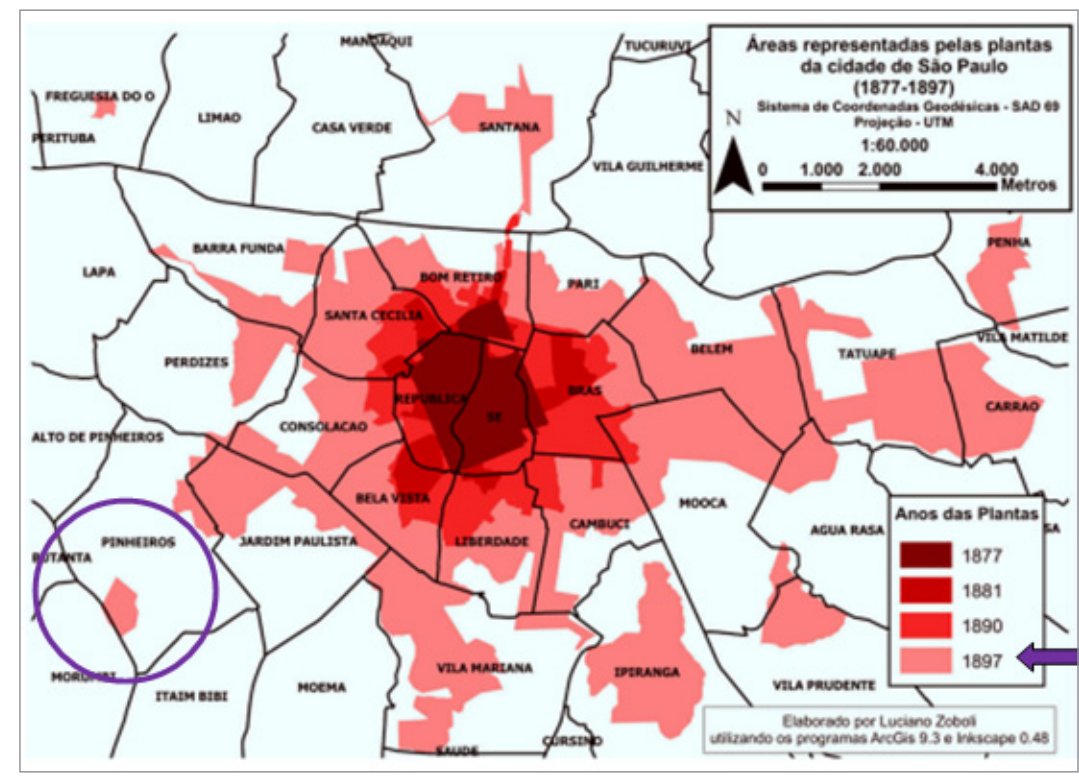

Figura 09. Áreas representadas pelas plantas da cidade de São Paulo (1877-1897) em FONSECA, Fernanda Padovesi; DUTENKEFER, Eduardo; ZOBOLI, Luciano; OLIVA, Jaime Tadeu. Cartografia digital geo-histórica: uma avaliação da mobilidade urbana de São Paulo no final do século XIX e início do século XX. Revista do Instituto de Estudos Brasileiros, Brasil, n. 64, p. 131-166, ago. 2016. Organizado pela autora. Acesso em 10/06/2018.

\section{O LARGO DA BATATA: CONSÓRCIOS E COLETIVOS}

Em 1904 chega ao bairro a linha de bonde conectando Pinheiros ao centro da cidade, mas inicialmente a linha que circula pela rua Teodoro Sampaio para no cruzamento com a Rua Capote Valente, impossibilitada de prosseguir até o largo de Pinheiros devido a áreas brejosas no caminho. Os passageiros são obrigados a percorrer descalços, um longo trecho íngreme até o ponto inicial da linha, carregando as botas nas mãos para não sujá-las com lama. Posteriormente, em 1909, a linha finalmente chega até o largo de Pinheiros, graças aos aterros providenciados pela empresa Light, responsável pelo fornecimento de energia e bondes elétricos (Fig. 10).

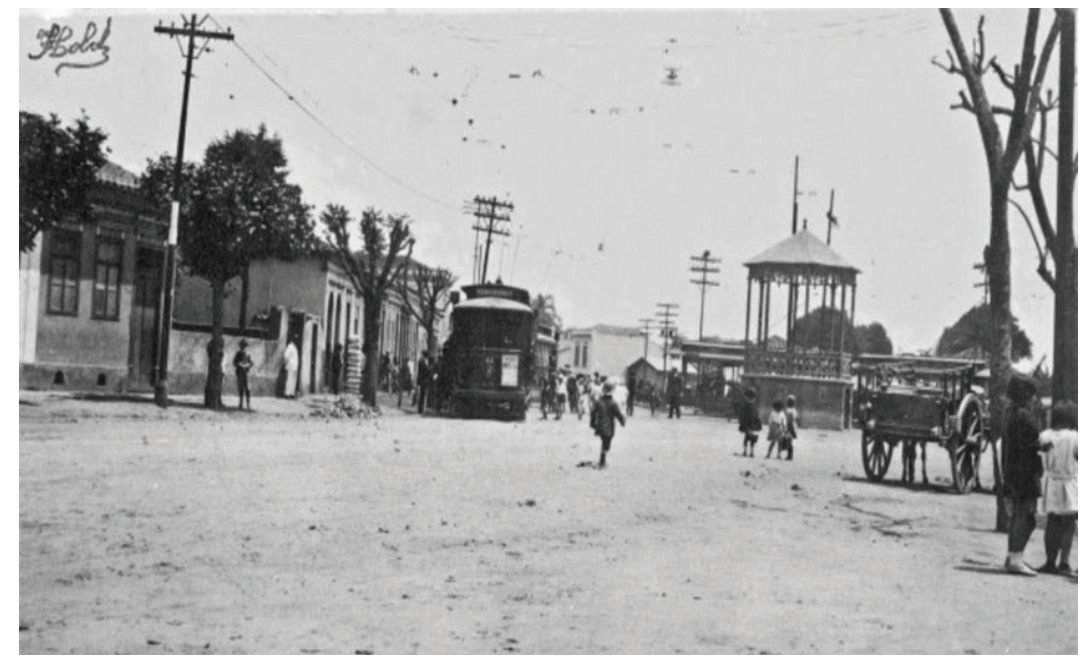

Figura 10. Largo de Pinheiros, anos 1900 - Raul Goldschmidt. Fonte:< http://gazetadepinheiros. com.br/uploads/Pinheiros_452_ Anos_6_grupo1_2.jpg/>. Acesso em 18/05/2018. 
A Light, que além da concessão de exploração das linhas de bonde em São Paulo é responsável pelo fornecimento de energia elétrica para as indústrias e iluminação pública, padece com os episódios de estiagem nos rios Tietê e Sorocaba que agravam o fornecimento de energia mesmo com aumento de capacidade das usinas de Sorocaba e Parnaíba (SMA, 2002). Asa White Kenney Billings - vice-presidente da Light pede em 1925 que F.S. Hyde realize um estudo de viabilidade para a geração e transmissão de energia em cachoeiras próximas à São Paulo. A grande enchente de 1929 é usada como uma das justificativas para o projeto de retificação do rio Pinheiros, que teria seu curso alterado direcionando suas águas para o reservatório Billings, que forneceria água para a Usina Henry Borden, localizada em Cubatão. A retificação e canalização do rio evitariam as inundações, facilitando a drenagem dos brejos e ocupação das várzeas, expandindo os ramais ferroviários e permitindo o loteamento de novos bairros pela Companhia City, que adquire vastas propriedades em Pinheiros antes mesmo de 1928 e demarca a linha perimétrica de enchente para definir terrenos à sua área de jurisdição (Fig. 11).

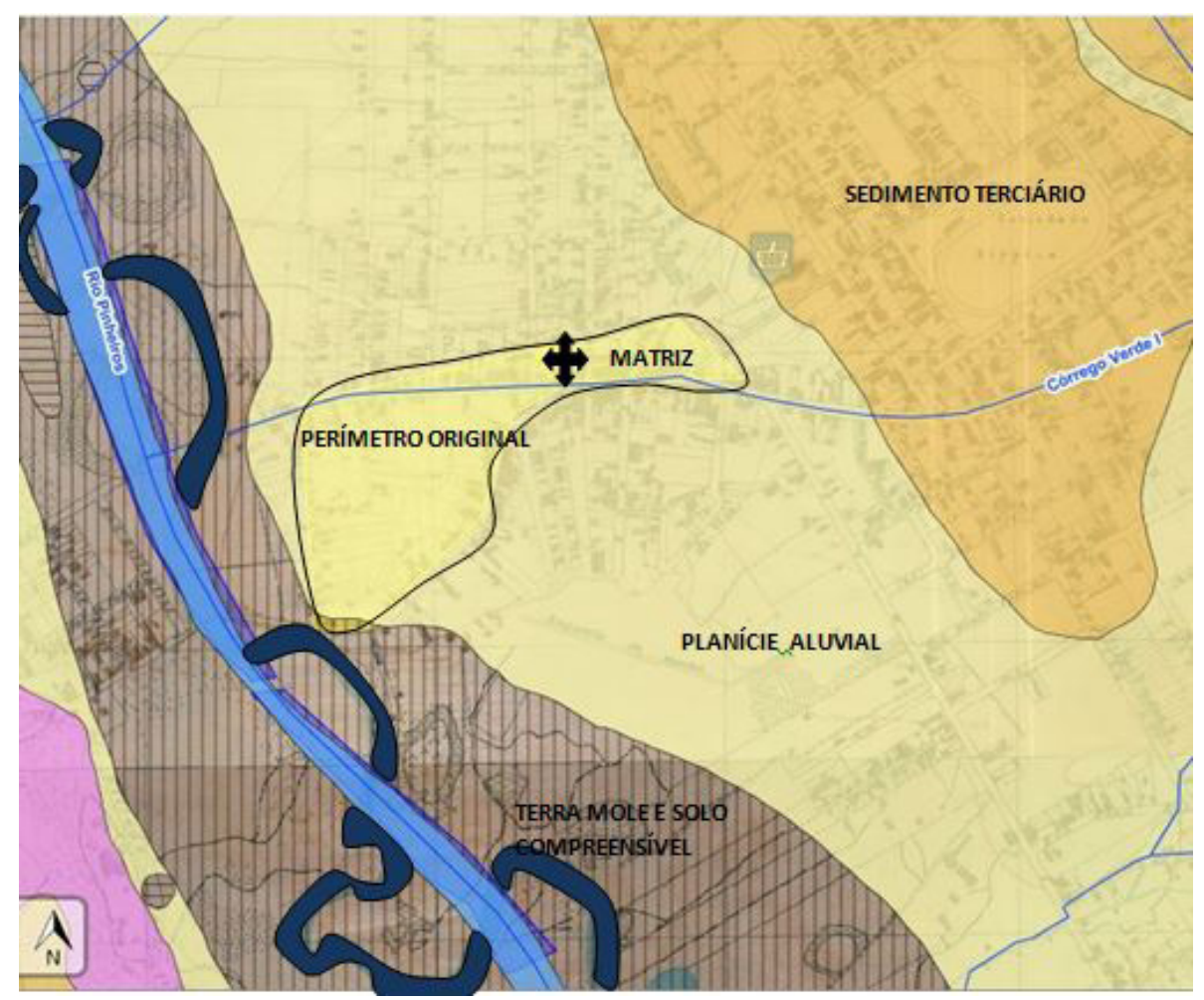

Figura 11. Planta do núcleo original do bairro de Pinheiros com a sobreposição do curso original do Rio Pinheiros (em azul escuro) e o curso atual com a retificação (azul claro). Adaptado do mapa Topographico do Município de São Paulo. Sara Brasil, 1930, folha 35. Organizado pela autora. Fonte: <http://geosam pa.prefeitura.sp.gov.br/PaginasPublicas/_SBC.aspx /> Acesso em 18/05/2018. 
A ocupação das áreas adjacentes ao bairro de Pinheiros, com novos loteamentos da Companhia City, como Jardim América, Alto da Lapa e depois Vila Madalena e Altos de Pinheiros começam a conectar o bairro às demais áreas da cidade. $O$ alargamento e pavimentação da Avenida Rebouças em 1935, que já era conhecida em 1904 como Doutor Rebouças, permite um acesso mais rápido da Rua da Consolação até a Rua Iguatemi. Na década de 1940, a construção da Avenida Eusébio Matoso, conecta a avenida ao bairro de Butantã, através de uma nova ponte de concreto, construída sobre o Rio Pinheiros, substituindo a antiga ponte de ferro, permitindo que a Companhia City promova a abertura de loteamentos na margem esquerda do rio Pinheiros. A nova sede do Jóquei Clube de São Paulo, estabelecida em 1941 em Cidade Jardim funciona como um chamariz para a ocupação do local. Na Rua Teodoro Sampaio, inicia-se no mesmo ano, o arruamento da área onde ficava a Hípica Paulista, provocando o adensamento das edificações no bairro e em torno do Largo da Matriz de Nossa Senhora de Monte Serrat, que novamente é reconstruída, perdendo suas feições coloniais e ganhando uma fachada num estilo mais românico. $O$ aumento das atividades comerciais e do trânsito de bondes e ônibus na região acaba ocasionando a mudança da hípica para um terreno no Brooklin e a inauguração da Igreja de São Paulo da Cruz, mais conhecida como Igreja do Calvário, pelos religiosos Passionistas, na Rua Cardeal Arcoverde, acaba angariando muitos dos fiéis para a nova congregação, que passa a concentrar as festas e quermesses juninas do bairro. A proximidade da paróquia com a Faculdade de Medicina, construída em parceria do governo do estado de São Paulo com a Fundação Rockfeller, e com o Hospital de Isolamento, ambas localizadas na Avenida Municipal, atual Avenida Doutor Arnaldo, contribui para a ocupação dessa área, até então bastante erma e isolada.

O modelo rodoviarista (ROLNIK, 2003), proposto por Prestes Maia em seu Plano de Avenidas, começa a ser implantado por toda a cidade de São Paulo, na década de 1940, incentivando o uso de ônibus ao invés dos bondes, por serem considerados mais flexíveis para acessar as periferias. Promove-se a abertura de avenidas por toda a cidade de São Paulo, a canalização e confinamento dos rios em galerias subterrâneas e a construção das marginais, ao longo dos Rios Tietê e Pinheiros, com trechos iniciais inaugurados respectivamente em 1957 e 1970. Em 1966 é inaugurado o primeiro shopping center de São Paulo, localizado na rua de mesmo nome, em terreno de uma chácara pertencente à família Matarazzo, trazendo uma nova concepção de exploração de espaços comerciais, voltados para uma classe mais abastada. No final da década de 1960 esse trecho compreendido entre a Rua Teodoro Sampaio e o Itaim é rebatizado como Avenida Brigadeiro Faria Lima, em memória ao ex-prefeito da 
cidade. Os bondes do Largo de Pinheiros são substituídos por terminais de ônibus no Largo da Batata e proliferam comércios informais de ambulantes e camelôs (Fig. 12), promovendo uma deterioração do local.

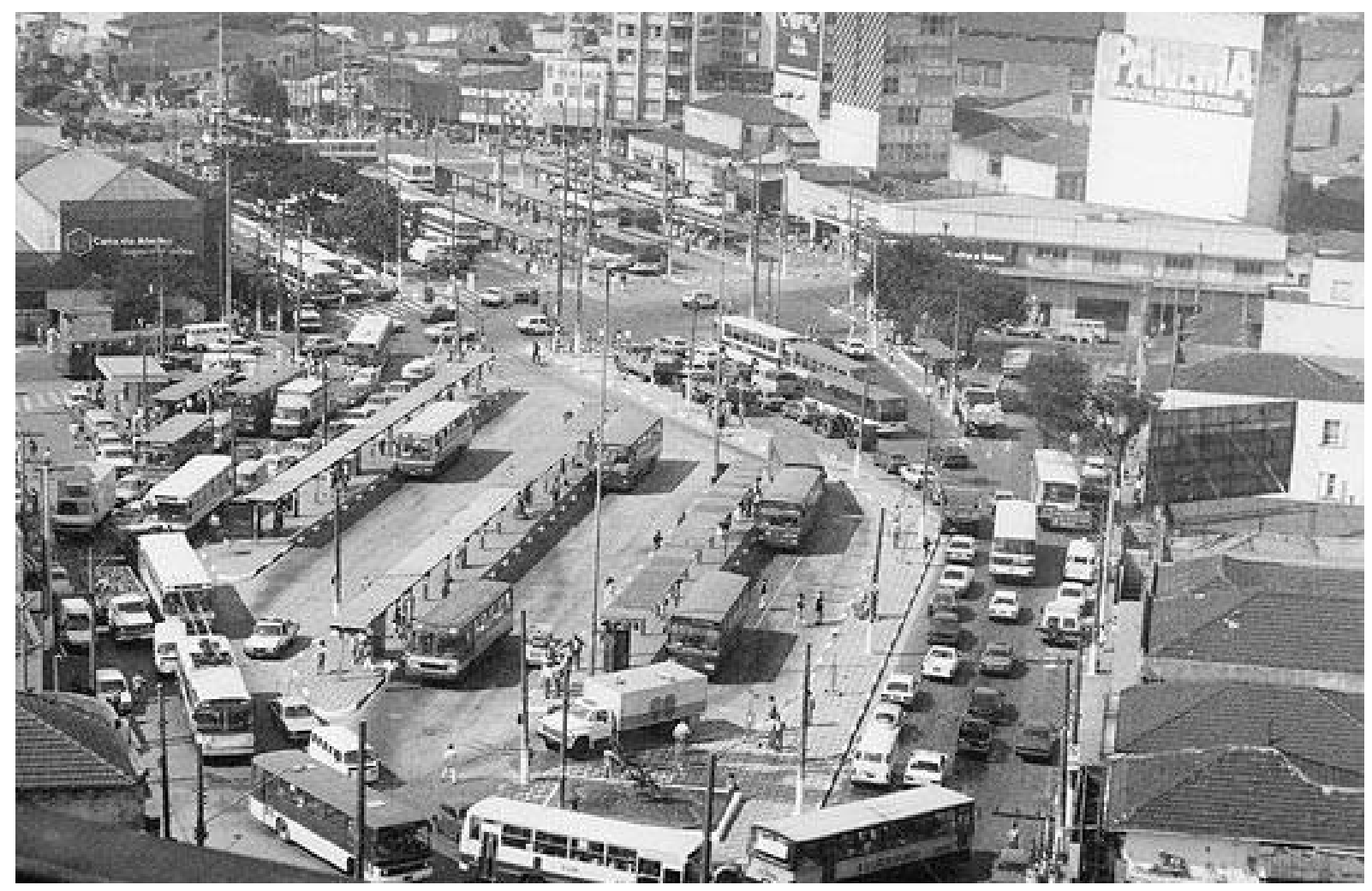

Figura 12. Terminal de ônibus do Largo da Batata. Fonte: < http://www.saopauloinfoco.com.br/wp-content/ uploads/2017/02/Terminal-de-\%C3\%B4nibus-no-largo-da-Batata-em-Pinheiros-no-ano-de-1991.jpg/> Acessado em 18/05/2018.

A promessa de extensão e conexões da Avenida Faria Lima com a Avenida Pedroso de Moraes e Avenida dos Bandeirantes começa a se concretizar em 1995, com a implantação do projeto urbanístico denominado Operação Consorciada Faria Lima, cujos objetivos visam mais do que apenas prolongar a avenida, buscando reorganizar o tráfego de carros e ônibus, construir um terminal multimodal de trens e metrô, transferindo o terminal de ônibus e reurbanizar o largo da Batata promovendo limpezas visuais e sociais no local. Busca-se uma valorização imobiliária do local, através da padronização visual arquitetônica com o restante da avenida e a implementação de edifícios mistos de serviços e residenciais.

As intervenções urbanas desagradam os moradores locais e a comunidade, que alegam que a área ficou descaracterizada e transformou-se em um deserto. Coletivos 
urbanos, como o movimento A Batata precisa de você, criado em 2014, procuram reorganizar e reocupar o espaço através de atividades e debates, promovendo eventos que conscientizem a população sobre a importância da reapropriação do espaço, do locus solus (ROSSI, 2001). Da mesma forma, outras organizações, como Águas Claras do Rio Pinheiros buscam a recuperação do rio.

\section{LARGO DE PINHEIROS X LARGO DA BATATA}

Quase todos os artigos que falam sobre o bairro de Pinheiros citam-no como um dos mais antigos, se não o mais antigo da cidade de São Paulo, como afirmam ZANETTI (1988), AMARAL (1985) e REALE (1982). Se considerarmos que sua fundação oficial ocorre em 1560, são 458 anos de existência e sobrevivência da área. Isso, por si só já é um sinal de resiliência. Mas, ser o bairro mais antigo de uma cidade também confere um status de importância ao local e motivo de orgulho para seus moradores, embora ironicamente no local nenhuma construção original tenha sido preservada.

A igreja, símbolo do locus urbe, da apropriação do espaço físico pelos jesuítas, foi reconstruída quatro vezes. Como sua localização é na confluência das ruas Paes Leme, Butantã, Pinheiros, Teodoro Sampaio e Avenida Brigadeiro Faria Lima manteve-se um espaço aberto localizado na frente de sua fachada, semelhante aos adros medievais, nomeado como Largo de Pinheiros. O mercado municipal e a cooperativa agrícola, símbolos da vocação comercial do bairro, localizados do outro lado do largo, também foram demolidos e reconstruídos. A cooperativa tornou a ser demolida, com a falência do CAC em 1994 e seu terreno tornou-se um vazio urbano ao lado da estação de metrô Faria Lima, disputada pelos empreendedores imobiliários. De sua memória sobraram apenas algumas fundações e o nome como o Largo de Pinheiros passou a ser chamado após a chegada da cooperativa ao bairro: Largo da Batata.

Inicialmente, o apelido tinha um caráter pejorativo, pois as condições de higiene e salubridade dentro e nos arredores dos entrepostos eram precárias. Mendigos, maltrapilhos e doentes circulavam nos arredores dos estabelecimentos (REALE, 1982). A presença dos imigrantes japoneses comercializando hortaliças e verduras também deveria causar estranhamentos. Quando os terminais de ônibus ocuparam o largo, que coincidiu com a vinda dos primeiros migrantes nordestinos à São Paulo, no final da década de 1960, proliferou o comércio informal de camelôs e ambulantes, disputando os fregueses com o comércio local. Considerando que a maior parte dos ônibus 
que partem dos terminais dirigem-se para as periferias mais pobres e distantes, 0 Largo da Batata permanece com o estigma de ser um local sujo e miserável. Só após a reurbanização da área, com a operação consorciada e a titulação oficial em 2012, transformando o Largo da Batata em logradouro, é que os coletivos adotam o espaço e o outrora apelido pejorativo passa a ser afetuoso.

A reurbanização, no entanto, tenta apagar todos os vestígios do que outrora tenha sido o Largo da Batata, mesmo tendo o poder público oficializado o seu nome. Tanto - Largo de Pinheiros, que com o crescimento do comércio no bairro, nas décadas de 1930 e 1940 perde parte de sua área externa para a criação de quadras comerciais e a Igreja de Monte Serrat, que na mesma época também sofre com a migração de seus fiéis para as igrejas próximas, voltam a ser os protagonistas do local, podendo novamente ser contemplados por quem circula na Avenida Brigadeiro Faria Lima, devido à demolição das quadras em frente ao largo, que obstruíam a visibilidade (Fig. 13 e 14). Substitui-se assim o caráter profano do locus, pelo retomada de seu viés sagrado.
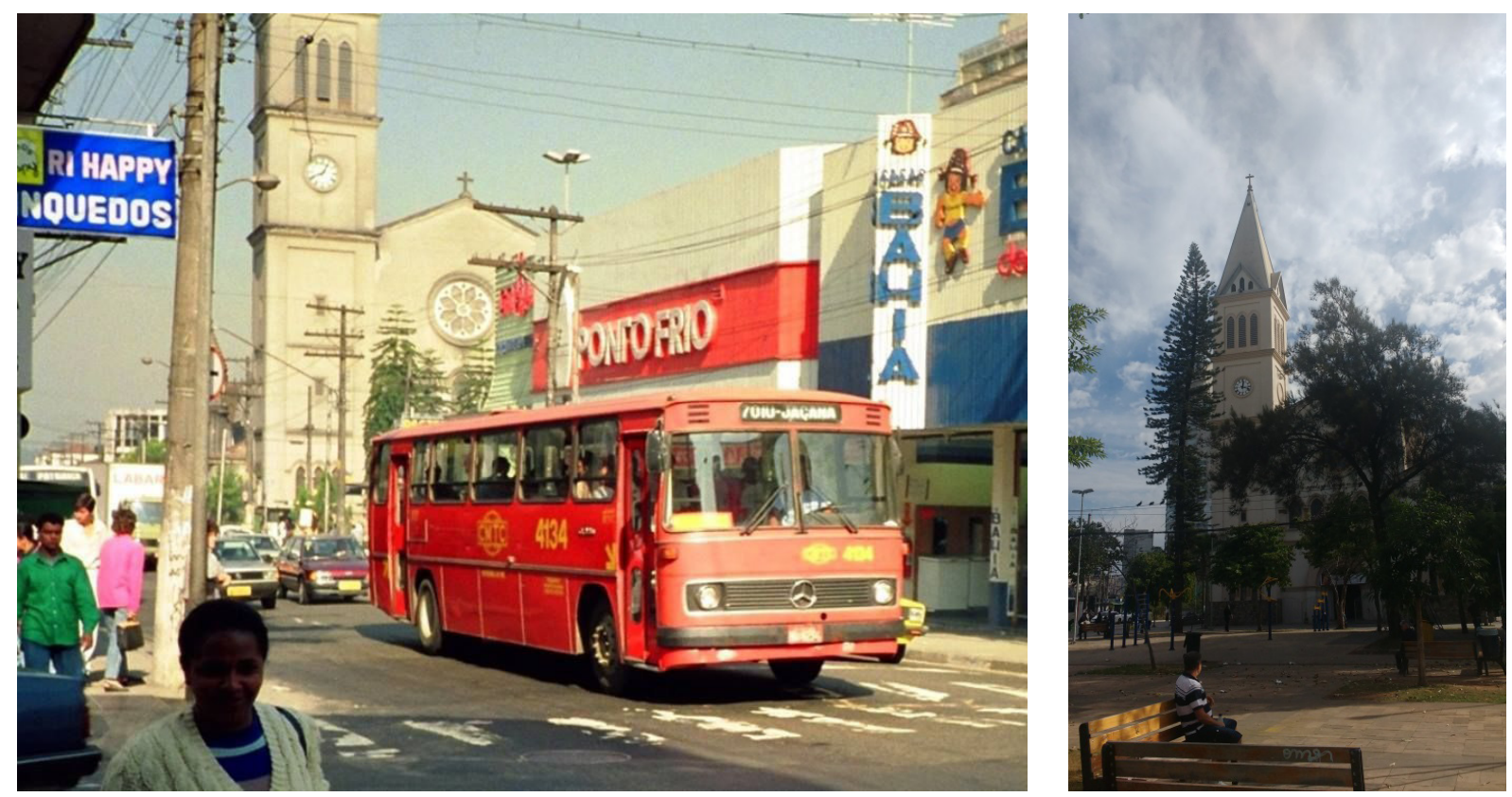

Figuras 13 e 14. Rua Paes Leme com a Igreja de Monte Serrat ao fundo e quadras frontais ocupadas por edificações e largo e Igreja após a reurbanização promovida pela Operação Consorciada. Fonte: < https://i.pinimg.com/originals/8c/1c/dd/8c1cdd70c043cd4a0af8b2022dffcc05.jpg/>. Acessado em $31 / 05 / 2018$ e foto da autora (11/06/2018), respectivamente.

O uso atual do largo pelos coletivos e pelos blocos durante o carnaval também criam vínculos da sociedade com o locus, laços afetivos com o meio ambiente, essência 
da topofilia, pois a apreciação da paisagem, mesmo que superficial, torna-se mais duradoura, pois envolve lembranças e sentimentos. O Largo da Batata é o cenário ideal dessa demonstração de topofilia, pois mesmo após a reurbanização mantem um tamanho compacto, podendo expressar os sentimentos locais de afeição e a consciência do passado: elemento importante no amor ao lugar.

Em contrapartida, quem apenas passa por baixo, fazendo uso da linha 4- Amarela do metrô, perde completamente a referência, pois falta o contato físico e o envolvimento. O próprio nome da estação - Faria Lima, é proposital, desvinculando o espaço físico subterrâneo com o espaço físico real e a memória. No entanto o locus original permanece: o traçado da linha 04 do metrô percorre a antiga trilha tupiniquim do Peaberu. "Com o tempo a cidade cresce sobre si mesma, adquire consciência e memória de si mesma" (ROSSI, 2001, pág. 2).

\section{CONSIDERAÇÕES FINAIS}

Yi Fu Tuan, no livro Topoffilia (1980), discorre no capítulo 04 sobre conceitos de etnocentrismo e estruturação de espaço e afirma que as ideias de centro e periferia são universais: o centro sempre transmite a sensação de segurança, mas ao mesmo tempo traz consigo a escuridão. A periferia, ao contrário, passa a ideia de liberdade e luz. À medida que os moradores distanciam-se do centro urbano, aumentam as relações de inferioridade dos habitantes da periferia em relação à área central, mas aumentam também os sentimentos de independência e resiliência. Considerando que Pinheiros só deixou de ser periferia no início do século $\mathrm{XX}$, e que por sua terras passaram os mais diversos tipos de indivíduos, culturas e etnias todas em busca de um lar, entende-se que o fator humano e as memórias coletivas também são elemento primordiais para a compreensão da resiliência social.

Para Farias (2017), “(...) resiliência é um processo que leva o homem a se reconectar com seu ambiente. Crise e resistência traduzem a resiliência social compreendida como a capacidade de um grupo ou comunidade, mantendo sua coesão, de se organizar para se adaptar às mudanças, aos riscos e às carências; é o esforço coletivo para melhorar o cotidiano, concentrando-se na solidariedade e tessitura diária dos laços sociais".

A resiliência urbana também pode ser observada nas atitudes que cada grupo toma frente aos obstáculos naturais, como o rio e o relevo. Os únicos que souberam convi- 
ver verdadeiramente com o rio, seus meandros e cheias foram os índios, habitantes originais do sítio urbano, responsáveis pela escolha do locus, com vidas governadas pelos ritmos sazonários da natureza (TUAN, 1980).

Nas palavras de ROSSI (2001) "(...) os lugares são mais fortes que as pessoas, o cenário mais que o acontecimento. A possibilidade da permanência é o único critério que permite que a paisagem ou as coisas construídas sejam superiores às pessoas". Dessa forma, a escolha do locus, e consequente genius loci provavelmente também são responsáveis pelas resiliências social e urbana observadas no decorrer dos séculos na área ocupada primeiramente pela aldeia de Pinheiros que depois passou a ser denominada de Largo de Pinheiros e Largo da Batata (Fig. 15).

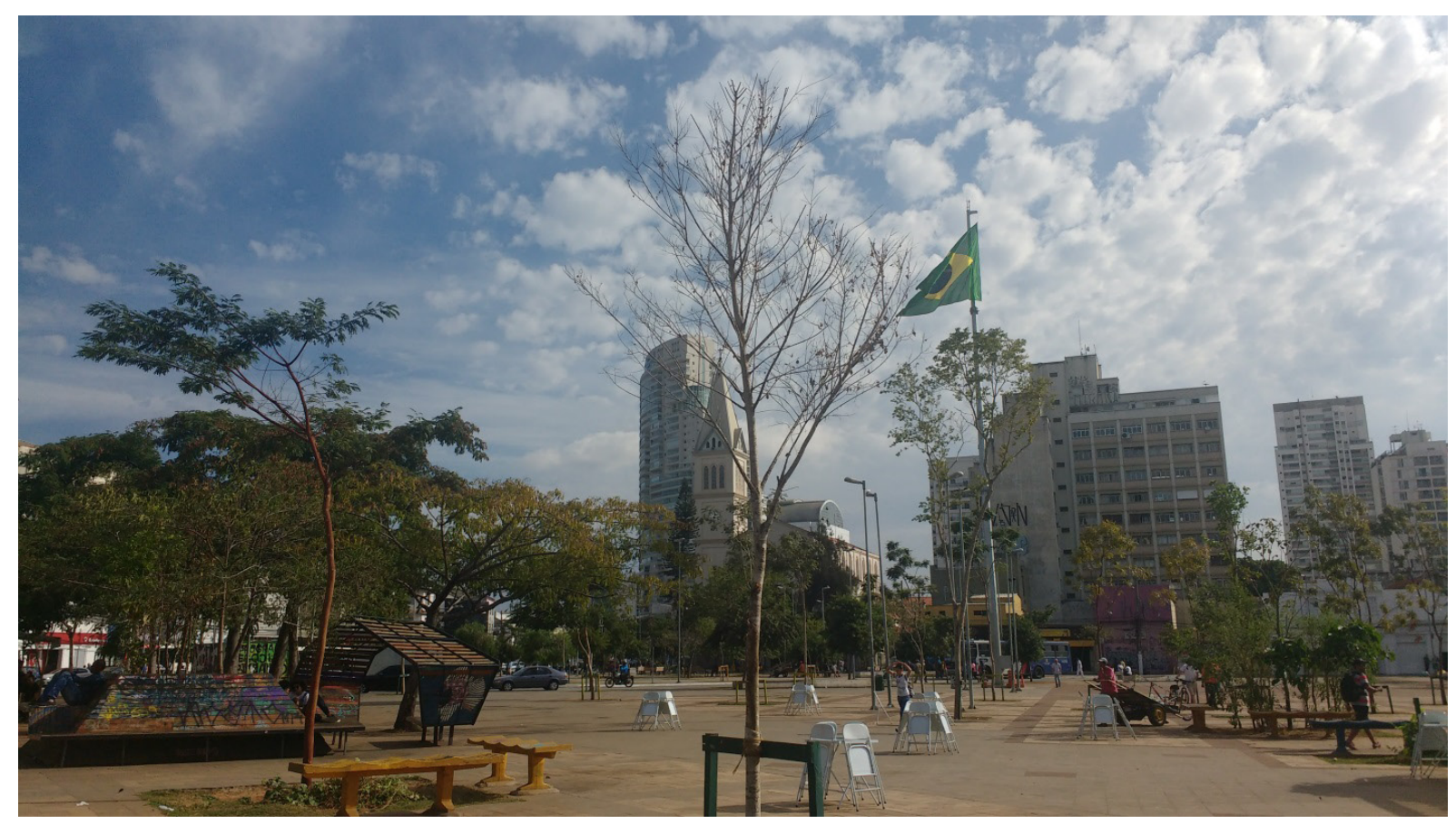

Figura 15. Paisagem atual do Largo da Batata. Foto da autora (11/06/2018). 


\section{REFERÊNCIAS}

AMARAL, Antônio B. O bairro de Pinheiros. São Paulo: Secretaria de Educação e Cultura, 1985.

BUENO, Beatriz P. S. Dilatação dos confins: caminhos, vilas e cidades na formação da Capitania de São Paulo (1532-1822). São Paulo : Anais do Museu Paulista. v. 17. n.2. jul.-dez. 2009. Disponível em:< http:www.revistas.usp.br/anaismp/article/view/5522> Acesso em: 03 jun. 2018.

CARDINALE, Ino. Genius loci e Locus genii: storie ed espressioni di uno spazio, senza tempo: identità di un territorio: da 'U curtigghiu 'nt'a 'u Curtigghiu a Sagra del Signore della nave / Ino Cardinale.- Castellammare del Golfo: GAL, 2016. Disponível em: < htt'://www.cinisionline.it > Appuntamenti/> Acesso em 02 jun. 2018.

CARDOSO, Victor J. M. Santo André, a vila perdida na borda do campo. Instituto de Biociências, Rio Claro: UNESP, 2016. Disponível em: < http://ib.rc.unesp.br/Home/Departamentos47/Botanica/victorjose/ santo-andre-a-vila-perdida.pdf/> Acesso em: 03 jun. 2018.

DICK, Maria V. P. A. A dinâmica dos nomes na cidade de São Paulo (1554-1897). São Paulo: Annablume, 1997.

FARIAS, José A. Resiliência: um bom conceito para o projeto e a reforma urbana? Artigo apresentado na XVII ENANPUR .São Paulo, 2017. Disponível em: < http://anpur.org.br/xviienanpur/principal/ publicacoes/XVII.ENANPUR_Anais/ST_Sessoes_Tematicas/ST\%2010/ST\%2010.6/ST\%2010.6-05. pdf/>. Acesso em: 31/05/2018.

FIGUEIREDO, Fernanda. Uma aldeia indígena urbana: um movimento de resistência visto sob a ótica de diferentes atores sociais. Dissertação de mestrado apresentada ao Departamento de Geografia PUC-Rio. Rio de Janeiro, 2012. Disponível em: <https://www.maxwell.vrac.puc-rio.br/21127/21127_1. PDF/> Acesso em 31 maio 2018.

KATINSKY, Júlio R. Casas Bandeiristas: nascimento e reconhecimento da arte em São Paulo. São Paulo: IGEOG -USP, 1976.

KIMURA, Maria L. Y. Largo de Pinheiros. Trabalho de graduação interdisciplinar FAUUSP: São Paulo, 1975.

LIMA, Sheila C. S. Rebeldia no Planalto: a expulsão dos padres jesuítas da Vila de São Paulo de Piratininga no contexto da restauração (1627-1655). Dissertação de mestrado apresentado à Universidade Federal Fluminense, Departamento de História. Rio de Janeiro, 2006.MARX, Murilo. Cidade brasileira. São Paulo: Melhoramentos: EDUSP, 1980.

NAVARRETE, Gonzalo. São Paulo, da colônia ao caos. São Paulo, Folha Online, 29 out. 2002. Disponível em: <http://www1.folha.uol.com.br/folha/sinapse/ult1063u183.shtml/> Acesso em 03 jun. 2018. 
REALE, Abe. Brás, Pinheiros, Jardins: três bairros, três mundos. São Paulo: Pioneira/Edusp 1982.

REIS-ALVES, Luiz A. dos. O conceito de lugar. Arquitextos, São Paulo, ano 08, n. 087.10, Vitruvius, ago. 2007 Disponível em :<http://www.vitruvius.com.br/revistas/read/arquitextos/08.087/225/> Acesso em 02 jun. 2018.

ROCHA FILHO, Gustavo. A pré-história de São Paulo: a descoberta do passado. 2017. Disponível em: <http://historiadesaopaulo.com.br/a-pre-historia-de-sao-paulo-a-descoberta-do-passado/>. Acesso em: 10 jun. 2018.

ROLNIK, Raquel. São Paulo. São Paulo: Publifolha, 2003 - (Folha explica).

ROSSI, Aldo. A arquitetura da cidade. São Paulo: Martins Fontes, 2001.

SÃO PAULO (Estado). Secretaria do Meio Ambiente. O Rio Pinheiros / Secretaria do Meio Ambiente. São Paulo: SMA, 2002.

SILVA, Janice T. São Paulo: 1554-1880: discurso ideológico e organização espacial. São Paulo: Editora Moderna, 1984.

TOLEDO, Benedito L. A primeira ligação de São Paulo de Piratininga com o litoral. São Paulo: Estadão, 16 jul. 2016. Disponível em : <http://sao-paulo.estadao.com.br/blogs/edison-veiga/a-1a-ligacao-de-saopaulo-de-piratininga-com-o-litoral/> Acesso em: 03 jun. 2018.

UNIVERSIDADE DE SÃO PAULO. Departamento de Geografia. Pinheiros: aspectos geográficos de um bairro paulistano. São Paulo: Edusp, 1963.

ZANETTI, Valdir Z. A produção da forma urbana: Pinheiros, São Paulo (1890-1980). Dissertação de mestrado apresentado à FAUUSP: São Paulo, 1988. 